\title{
Human Papillomavirus Cervical Infection and Associated Risk Factors in a Region of Argentina With a High Incidence of Cervical Carcinoma
}

\author{
S.A. Tonon, ${ }^{1 *}$ M.A. Picconi, ${ }^{2}$ J.B. Zinovich, ${ }^{3}$ D.J. Liotta, ${ }^{1}$ P.D. Bos, ${ }^{1}$ \\ J.A. Galuppo, ${ }^{4}$ L.V. Alonio, ${ }^{2}$ J.A. Ferreras, ${ }^{1}$ and A.R. Teyssié ${ }^{2}$ \\ ${ }^{1}$ Laboratorio de Biología Molecular Aplicada; Facultad de Ciencias Exactas, Quimicas y Naturales, \\ Universidad Nacional de Misiones, Argentina \\ ${ }^{2}$ Servicio Virus Oncogénicos, INEI, ANLIS, "Dr. Carlos G. Malbrán," Ministerio de Salud y \\ Acción Social de la Nación, Buenos Aires, Argentina \\ ${ }^{3}$ Hospital Provincial Central, "Dr. Ramón Madariaga," Misiones, Argentina; Federación Argentina \\ de Sociedades de Ginecologia y Obstetricia, Argentina \\ ${ }^{4}$ Cátedra de Citología e Histologia, Facultad de Ciencias Exactas, Quimicas y Naturales, \\ Universidad Nacional de Misiones, Argentina
}

\begin{abstract}
Objective: To assess the prevalence and potential risk factors associated with human papillomavirus (HPV) cervical infection among women residing in a region of northeastern Argentina with a high incidence of cervical cancer.

Methods: A case-control study of 330 women participating in a cervical cytological screening program conducted in Posadas city, Misiones, Argentina, from February 1997 to November 1998 was carried out. Standardized questionnaires were administered, and clinical examination including colposcopy was performed. Fresh endocervical specimens for HPV DNA detection by generic polymerase chain reaction were collected and the products typed by dot-blot hybridization.

Results: Human papillomavirus DNA was found in $61 \%$ of samples analyzed (185/301). Samples with normal cytology had a $43 \%$ infection rate (85/199), while those classified as low-grade squamous intraepithelial lesion, high-grade squamous intraepithelial lesion, and invasive cervical carcinoma had an infection rate of $96 \%(53 / 55), 100 \%(29 / 29)$, and $100 \%(18 / 18)$, respectively. Human papillomavirus typing showed a $64 \%(118 / 185)$ prevalence of type 16 among all the infected population analyzed; type 16 was detected among $49 \%$ (42/85) of infected samples with normal cytology and in an average of $74 \%(74 / 100)$ with abnormal cytology. Sexual behavior, residence in southern Paraguay, and history of a previous sexually transmitted diseases were the main risk factors associated with high-grade cervical lesions.

Conclusions: An elevated prevalence of HPV infection was detected in this population, which also has a high incidence of cervical cancer. The broad distribution of high-risk HPV type 16 in women with normal cytology and colposcopy suggests that viral infection is an important determinant of

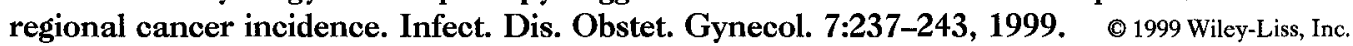

KEY WORDS

cervical neoplasms; human papillomavirus; risk factors; northeastern Argentina

A ssociations between human papillomavirus (HPV) and cervical neoplasia have been reported consistently. ${ }^{1}$ International studies have shown that cervical cancer is the second most com- mon cause of cancer in women worldwide, with a prevalence that varies $(1-4$ cases in 10,000$)$ according to the implementation of successful public health programs for screening and treatment. ${ }^{2}$

*Corresponding author: Dr. Sergio Andrés Tonon, Facultad de Ciencias Exactas, Químicas y Naturales, Universidad Nacional de Misiones, Félix de Azara 1552, Posadas, Misiones -3300, Argentina. E-mail: tonon@arnet.com.ar 
Different HPV types have been detected in more than $95 \%$ of cases of invasive cervical cancer (ICC) and in varying percentages in cases of lowgrade squamous intraepithelial lesion (LSIL) and high-grade squamous intraepithelial lesion (HSIL). ${ }^{3-8}$

Studies examining risk factors for HPV infection have not been entirely consistent, ${ }^{9,10}$ probably due to differences in the studied populations and the detection methods used. It would be of importance to focus on particular characteristics of the population under study, such as demographic growth rate, regional human displacement around the area under analysis, and sexual habits, as well as overall HPV prevalence and presence of specific HPV types.

In Argentina, there are still no complete epidemiologic data to state the actual, global situation regarding HPV infection and its association with cervical neoplasia. Nevertheless, regional studies have shown that cervical cancer incidence varies widely, with values that range from 1-3 cases per 10,000 women residing in metropolitan areas to 4 cases per 1,000 women in peripheral regions. ${ }^{11}$

The Province of Misiones is situated at the northeastern tip of Argentina and shares international borders with Paraguay and Brazil. The construction in the last ten years of bridges and roadways and the creation of a common market including these three countries have promoted an intense population migration along the entire territory. This new situation has changed several cultural habits.

Since the implementation of a program of cervical cancer screening by cytology in 1995 in Misiones, an elevated incidence of 3-4 cases of ICC per 1,000 women has been reported consistently, together with high incidences of LSIL (16 per $1,000)$ and HSIL (11 per 1,000).

These values have defined an area of high cancer incidence where some particular factors probably are involved. ${ }^{12,13}$ The aim of this study was to assess the HPV prevalence and potential risk factors associated with viral cervical infection among women from this region.

\section{SUBJECTS AND METHODS}

\section{Study Population}

Three hundred and thirty women were recruited from 5,676 participants attending either the Cen- tral Regional Hospital, two family practice clinics in Posadas, (Misiones, Argentina) or a clinic in Encarnacion (Paraguay) as part of an ongoing cervical cancer screening program from February 1997 to November 1998.

A written informed consent form was signed by all participants, and a standardized, self-administered questionnaire concerning sociodemographic factors, sexual and reproductive history, use of birth control, and history of other sexually transmitted diseases was completed. All women underwent a standard gynecologic examination and colposcopy, during which material for Papanicolaou smears was collected with cytobrush. To minimize the bias in sample collection and to ensure a sufficient amount of exfoliated cells, sampling was performed only if the last menstruation had occurred at least one week before the exam. The Pap test diagnosis was used to classify subjects as controls (normal changes) or cases (LSIL, HSIL, or ICC). ${ }^{14}$

The case group included all tested women with abnormal cytology and/or abnormal colposcopy ranging from LSIL to ICC. Fifty nine participants were diagnosed with LSIL, 33 with HSIL, and 18 with ICC (all of the squamous cell type).

For each case, two population-based controls were selected and matched for age of subject and time when the sample was collected. This control group included 220 women with normal colposcopy and cytology and no history of sexually transmitted diseases or HPV lesions. For the case-control trios above 65 years old, an age difference of 5 years was tolerated for matching purposes.

Biopsies were taken from abnormal areas and under direct colposcopic vision when necessary. Histopathologic examination was carried out, and the final diagnosis was based on the worst morphologic picture.

\section{Human Papillomavirus DNA Analysis}

Human papillomavirus detection samples were obtained from the ecto- and endocervix using cytobrush and processed the same day of collection. Cytobrushes were washed with sterile phosphatebuffered saline solution, $\mathrm{pH} 7.4$, and collected cells lysed adding $200 \mu \mathrm{g} / \mathrm{mL}$ of proteinase $\mathrm{K}$ in the presence of $0.5 \%$ SDS in a total reaction volume of $500 \mu \mathrm{L}$ of cellular suspension and incubated for 1 hour at $55^{\circ} \mathrm{C}$. Nucleic acid was extracted as described previously. ${ }^{15}$ Isolated DNA were tested by 
polymerase chain reaction (PCR) for betaglobin gene to confirm the presence of an adequate and amplifiable template in the samples. ${ }^{16}$

The DNA was amplified with the general consensus primers GP5+ and GP6+, targeting a region of approximately 140 base pairs in the highly conserved L1 ORF of the HPV viral genome. ${ }^{17}$ DNA from CaSki and HeLa cells were used as positive controls; negative controls included no template DNA and were included after each tenth specimen in all tests.

The PCR reactions were carried out in $50 \mu \mathrm{L}$ of solution containing $10 \mu \mathrm{L}$ of template DNA, 10 $\mathrm{mM}$ Tris $\mathrm{HCl}$ (pH 8.3), $50 \mathrm{mM} \mathrm{KCl,} 3 \mathrm{mM} \mathrm{MgCl}$, $100 \mu \mathrm{M}$ dATP, dCTP, dTTP and dGTP, $10 \mathrm{pmol}$ of each primer, and $2 \mathrm{U}$ of AmpliTaq ${ }^{\mathrm{TM}}(5 \mathrm{U} / \mu \mathrm{L}$; Perkin Elmer, New Jersey). A hot start technique was used; the thermal cycling conditions were $94^{\circ} \mathrm{C}$ for 3 minutes, followed by 40 cycles at $93^{\circ} \mathrm{C}$ for 30 second, $45^{\circ} \mathrm{C}$ for 30 seconds, and $72^{\circ} \mathrm{C}$ for $30 \mathrm{sec}$ onds.

The amplification products were analyzed on $1.5 \%$ agarose gels, visualized with ethidium bromide staining and ultraviolet light exposure, and photographed. A single band of approximately 140 base pairs indicated a positive sample.

\section{Dot-Blot Hybridization}

Thirty-microliter aliquots resulting from positive HPV generic PCR were denatured with $20 \mu \mathrm{L}$ of $1 \mathrm{~N} \mathrm{NaOH}$ and dot-blotted to Zeta ${ }^{\mathrm{TM}}$ probe membranes (BioRad, California). Positive and negative controls were included in each assay. Biotinlabeled oligonucleotides type-specific probes for HPV types $6,11,16$, and 18 were used. ${ }^{18}$ Hybridization was performed at $55^{\circ} \mathrm{C}$ for 3 hours. Filters were washed twice for 10 minutes at $56^{\circ} \mathrm{C}$ for $\mathrm{HPV}$ types 6 and 11 and at $58^{\circ} \mathrm{C}$ for HPV types 16 and 18. Positive hybridization dots were developed by chemoluminescence (PhotoGene ${ }^{\mathrm{TM}}$ nucleic acid detection system, BRL, Grand Island, NY). Specimens that showed a band of approximately 140 base pairs by ethidium bromide visualization but that could not be typed with the type-specific probes were referred to as "other HPV."

\section{Statistical Analysis}

The association between risk factors and the presence of HPV or lesion grade was assessed by univariate analysis, ${ }^{19}$ yielding estimates of the odds
TABLE I. General characteristics of the study population

\begin{tabular}{|c|c|c|}
\hline Characteristic & Cases & Controls \\
\hline Median age (range, $17-69$ y) & $34 y$ & $32 y$ \\
\hline \multicolumn{3}{|l|}{ Median age at first intercourse } \\
\hline (range, 14-25 y) & $18 y$ & $20 y$ \\
\hline \multicolumn{3}{|l|}{ Median age at first pregnancy } \\
\hline (range, 16-36 y) & $23 y$ & $22 y$ \\
\hline \multicolumn{3}{|l|}{ Lifetime no. of sex partners } \\
\hline 1 & $24 \%$ & $28 \%$ \\
\hline $2-5$ & $47 \%$ & $45 \%$ \\
\hline$>5$ & $29 \%$ & $27 \%$ \\
\hline \multirow{2}{*}{\multicolumn{3}{|c|}{$\begin{array}{l}\text { History of sexually transmitted } \\
\text { diseases }\end{array}$}} \\
\hline & & \\
\hline Yes & $21 \%$ & $0 \% *$ \\
\hline No & $79 \%$ & $100 \% *$ \\
\hline \multicolumn{3}{|l|}{ Use of oral contraceptives } \\
\hline Yes & $49 \%$ & $36 \% * *$ \\
\hline No & $35 \%$ & $53 \% * *$ \\
\hline Other forms & $16 \%$ & $11 \%$ \\
\hline \multicolumn{3}{|l|}{ Marital status } \\
\hline Married & $58 \%$ & $60 \%$ \\
\hline Single & $30 \%$ & $32 \%$ \\
\hline Widow/divorced & $12 \%$ & $8 \%$ \\
\hline \multicolumn{3}{|l|}{ Place of permanent residence } \\
\hline Northeastern Argentina & $68 \%$ & $65 \%$ \\
\hline Southern Paraguay & $32 \%$ & $35 \%$ \\
\hline \multirow{2}{*}{\multicolumn{3}{|c|}{$\begin{array}{l}\text { Frequency of displacement } \\
\text { between countries }\end{array}$}} \\
\hline & & \\
\hline Once a week or less & $61 \%$ & $56 \%$ \\
\hline Twice a week or more & $39 \%$ & $44 \%$ \\
\hline \multicolumn{3}{|l|}{ Socioeconomic status } \\
\hline Upper/middle class & $62 \%$ & $59 \%$ \\
\hline Low income & $38 \%$ & $41 \%$ \\
\hline \multicolumn{3}{|l|}{ Education } \\
\hline Completed high school & $64 \%$ & $68 \%$ \\
\hline Did not complete high school & $36 \%$ & $32 \%$ \\
\hline
\end{tabular}

*Significant difference $(P<0.001)$.

**Significant difference $(P<0.005)$.

ratio (OR); 95\% confidence intervals (CI) gauged the precision of the OR estimates. These analyses were carried out using the Epi Info program (Centers for Disease Control, Atlanta, GA).

\section{RESULTS}

The general characteristics of the study population at entry are summarized in Table 1 . Interviews were successfully completed for 330 subjects during the accrual period. The cervical specimens from 11 subjects were not evaluable because of problems in transport or material quality. An additional set of 18 specimens failed to be amplified for betaglobin. The present analysis refers to the remaining 301 evaluable participants, 199 with normal cytology (control group); 55 with LSIL, 29 with HSIL, and 18 with ICG (cases group). 
TABLE 2. Odds ratio associating HPV infection with abnormal cytology

\begin{tabular}{|c|c|c|c|}
\hline & Controls & Cases & \\
\hline & $\begin{array}{c}\text { No. subjects } \\
(\%)\end{array}$ & $\begin{array}{l}\text { No. subjects } \\
(\%)\end{array}$ & OR $(95 \% \mathrm{Cl})$ \\
\hline HPV (-) & $114(57)$ & $2(1.9)$ & 1.0 \\
\hline HPV (+) & $85(43)$ & $100(98.1)$ & $67(39.3-74.5)$ \\
\hline Total & 199 & 102 & \\
\hline
\end{tabular}

The median age was 33 years old, with an age range from 17 to 69 years. There were 33 subjects $(11 \%)$ who were under 20 years old; $58(19.3 \%)$ were $20-29$ years old, $113(37.5 \%)$ were $30-39$ years old, $55(18.3 \%)$ were $40-49,23(7.6 \%)$ were $50-60$ years old, and $19(6.3 \%)$ were over age 60 years.

Human papillomavirus DNA was found in $61 \%$ of samples analyzed (185/301). In the control group, $43 \%$ (85/199) of samples were positive for HPV, while those with LSIL, HSIL, or ICC were HPV positive in $96 \%(53 / 55), 100 \%$ (29/29), and $100 \%(18 / 18)$ of cases, respectively. Table 2 shows the strong association of HPV infection (crude OR, 67) with abnormal cytology.

HPV typing results are presented in Table 3. Infections with two viral types were detected in 17 women $(20 \%)$ from the cases group; eight with LSIL cytology (15\%) and nine with HSIL (31\%). Among the LSIL cases with mixed infections, five had HPV types 11 and 16, and three had HPV types 16 and 18. In those with HSIL cytology, five samples showed HPV 6 and 16, two showed HPV 11 and 16, and two showed HPV 16 and 18.

The most prevalent type was HPV 16 , which was detected in $49 \%(42 / 85)$ of infected samples from the control group (overall prevalence, $21 \%$ ), in $77 \%$ of those with LSIL, in $72 \%$ of those with HSIL, and in $67 \%$ of those with ICC.

The association of HPV-16 infection and abnormal cytology is presented in Table 4. The association between selected variables (potential risk factors) of the cases group and abnormal cytology is presented in Table 5. Early age at first sexual intercourse, multiple lifetime number of sex partners, early age of first pregnancy, residence in southern Paraguay, and history of previous sexually transmitted diseases correlated significantly to HSIL and ICC lesions.

Univariate analysis of the same variables in HPV-positive subjects who were in the control group is shown in Table 6. Strong associations are
TABLE 3. Prevalence of HPV DNA in controls and cases

\begin{tabular}{|c|c|c|c|c|c|c|}
\hline \multirow{2}{*}{$\begin{array}{l}\text { No. } \\
\text { subjects }\end{array}$} & \multirow{2}{*}{$\begin{array}{c}\text { Overall } \\
\text { HPV } \\
\text { positivity } \\
(\%)\end{array}$} & \multicolumn{5}{|c|}{$\begin{array}{l}\text { HPV type-specific } \\
\text { positivity (\%) }\end{array}$} \\
\hline & & 6 & II & 16 & 18 & Other \\
\hline 199 controls & 43 & 7.5 & 2.0 & 21.1 & 3.0 & 9.0 \\
\hline 55 LSIL $^{b}$ & 96 & 5.7 & 17.0 & 77.3 & 13.2 & 1.9 \\
\hline $29 \mathrm{HSIL}^{\mathrm{b}}$ & 100 & 27.6 & 13.8 & 72.4 & 13.8 & 3.5 \\
\hline $18 \mathrm{ICC}^{\mathrm{c}}$ & 100 & 0 & 0 & 66.6 & 17.4 & 16.0 \\
\hline
\end{tabular}

airal types other than 6, 11, 16, or 18.

bType-specific percentages include multiple types infections.

'Squamous-cell type carcinoma.

TABLE 4. Association of HPV type 16 infection with abnormal cytology

\begin{tabular}{lcr}
\hline & $\begin{array}{c}\text { HPV 16 } \\
\text { prevalence (\%) }\end{array}$ & OR $(95 \% \mathrm{Cl})$ \\
\hline $\begin{array}{l}\text { Controls infected } \\
\text { 85 }\end{array}$ & & \\
Cases $^{\mathrm{a}}$ (no. and type) & 21.1 & \\
53 LSIL & & \\
29 HSIL & 77.3 & $12.7(4.7-35.1)$ \\
18 ICC & 72.4 & $9.6(3.6-30.4)$ \\
\hline
\end{tabular}

aAny HPV type.

found between HPV infection and multiple lifetime number of sex partners and early age at first sexual intercourse; there are weaker correlations with frequency of displacement between Posadas (Argentina) and Encarnacion (Paraguay), use of oral contraceptives, and low socioeconomic status.

\section{DISCUSSION}

Cervical carcinoma is the leading cause of death by cancer in women in the Province of Misiones, Argentina, with an elevated incidence of 3 cases per 1,000 . This value is particularly high compared with other regions of the country ( 1 case in 10,000 on average) where data are available. This situation prompted us to conduct a case-control study to investigate HPV infection in the female population as a condition necessary but not sufficient for progression to cervical neoplasia ${ }^{3-8}$ and to analyze some regional factors probably associated with it. The study group was representative of the regional population and was characterized by married, middle-class, well-educated women.

In the analysis of HPV DNA present in cervical samples from the control group, we found an elevated percentage of viral infection (43\%), showing predominantly HPV type 16 . As the role of certain 
TABLE 5. Association of abnormal cytology with selected variables in the cases group

\begin{tabular}{|c|c|c|c|c|c|c|}
\hline & LSIL & & HSIL & & ICC & \\
\hline Variable & $n=53(\%)$ & OR $(95 \% \mathrm{Cl})$ & $\mathrm{n}=29(\%)$ & OR $(95 \% \mathrm{Cl})$ & $n=18(\%)$ & OR $(95 \% \mathrm{Cl})$ \\
\hline \multicolumn{7}{|l|}{ Age at first intercourse $(y)$} \\
\hline $22-25$ & $18(34.0 \%)$ & 1.0 & $5(17.2 \%)$ & 1.0 & $2(11.1 \%)$ & 1.0 \\
\hline$|8-2|$ & $21(39.6 \%)$ & $1.3(0.7-2.6)$ & II (37.9\%) & $2.9(1.9-4.3)$ & $6(33.3 \%)$ & $4.0(2.7-6.1)$ \\
\hline $14-17$ & $14(26.4 \%)$ & $0.7(0.5-1.1)$ & $13(44.9 \%)$ & $3.9(2.5-5.6)$ & $10(55.6 \%)$ & $6.2(4.6-10.8)$ \\
\hline \multicolumn{7}{|l|}{ Lifetime no. of sex partners } \\
\hline 1 & $12(22.6 \%)$ & 1.0 & $5(17.2 \%)$ & 1.0 & $3(16.6 \%)$ & 1.0 \\
\hline $2-5$ & $22(4 \mid .5 \%)$ & $2.4(1.2-3.4)$ & $13(44.8 \%)$ & $3.9(2.5-5.2)$ & $8(44.4 \%)$ & $4.0(2.4-6.1)$ \\
\hline$>5$ & $19(35.9 \%)$ & $1.9(0.9-2.5)$ & II (38.0\%) & $2.9(1.8-4.5)$ & $7(39.0 \%)$ & $3.2(2.1-4.9)$ \\
\hline \multicolumn{7}{|l|}{ Age at first pregnancy $(y)$} \\
\hline $30-36$ & $14(26.4 \%)$ & 1.0 & $6(20.1 \%)$ & 1.0 & $3(16.6 \%)$ & 1.0 \\
\hline $2 I-29$ & $21(39.6 \%)$ & $1.8(1.3-3.1)$ & $9(31.0 \%)$ & $1.7(1.2-3.0)$ & $7(38.9 \%)$ & $3.2(2.5-5.1)$ \\
\hline $16-20$ & $18(34.0 \%)$ & $1.5(1.1-2.7)$ & $14(48.9 \%)$ & $3.6(2.7-5.4)$ & $8(44.5 \%)$ & $4.0(2.9-5.9)$ \\
\hline \multicolumn{7}{|l|}{ Place of permanent residence } \\
\hline Northeastern Argentina & $29(54.7 \%)$ & 1.0 & $10(34.5 \%)$ & 1.0 & $6(33.3 \%)$ & 1.0 \\
\hline Southern Paraguay & 24 (45.3\%) & $0.8(0.6-1.2)$ & $19(65.5 \%)$ & $3.6(2.6-5.1)$ & $12(66.7 \%)$ & $4.0(2.8-6.0)$ \\
\hline \multicolumn{7}{|c|}{$\begin{array}{l}\text { History of sexually transmitted } \\
\text { diseases }\end{array}$} \\
\hline No & $37(69.8 \%)$ & 1.0 & II (37.9\%) & 1.0 & $7(38.8 \%)$ & 1.0 \\
\hline Yes & $16(30.2 \%)$ & $0.4(0.2-0.7)$ & $18(62.1 \%)$ & $2.7(1.5-3.6)$ & $11(61.2 \%)$ & $2.5(1.7-3.9)$ \\
\hline \multicolumn{7}{|l|}{ Use of oral contraceptives } \\
\hline No & $24(45.3 \%)$ & 1.0 & II (37.9\%) & 1.0 & $11(6 I .1 \%)$ & 1.0 \\
\hline Yes & $29(54.7 \%)$ & $1.5(0.3-2.5)$ & $18(62.1 \%)$ & $2.7(1.9-3.5)$ & $7(38.9 \%)$ & $0.5(0.3-1.0)$ \\
\hline \multicolumn{7}{|l|}{ Socioeconomic status } \\
\hline Upper/middle class & $32(60.4 \%)$ & 1.0 & $13(44.8 \%)$ & 1.0 & $7(38.9 \%)$ & 1.0 \\
\hline Low income & $21(39.6 \%)$ & $0.7(0.5-1.1)$ & $16(55.2 \%)$ & $1.5(0.8-2.1)$ & $11(61.1 \%)$ & $2.5(1.4-3.6)$ \\
\hline
\end{tabular}

HPV types $(16,18,31,33$, and 45$)$ in cervical carcinogenesis becomes indisputable, the detection of these HPV types in cervical samples is being considered in conjunction with cytology ${ }^{20}$ to improve diagnostic accuracy and efficiency.

A comparatively high level of HPV generic infection and HPV 16 prevalence values in cytologically normal women have been reported by Kjaer et al. in a population-based study done in Greenland. ${ }^{10}$ Similar studies carried out in areas with a high incidence of cervical cancer in South America, such as Recife, Brazil, ${ }^{8}$ and Colombia, ${ }^{21}$ have reported lower total HPV infection prevalences (13\% and $9 \%$, respectively).

Cervical HPV infection detected by PGR technique is found in 5-50\% of asymptomatic women of reproductive age presenting for Pap test screening in different countries. ${ }^{1}$ When additional cervical specimens are taken from these women in follow-up surveys, the majority of the infections are found to be transient, and only a small proportion of women tend to harbor the same HPV type in subsequent samples. ${ }^{22}$ Prospective epidemiological studies suggest that only persistent infection with high-risk HPV types of the cervical epithelium trigger tumor development. ${ }^{20}$ However, knowing that cervical cancer poses an important problem in this region, our data showing a high prevalence of HPV types 16 and 18 in healthy women are of significant value and should be considered in public health policy program implementation.

Univariate risk factors analysis of the control group yielded strong associations between HPV infection and sexual behavior (lifetime number of sexual partners and early age at first intercourse), and a weak but interesting association with low socioeconomic status and the frequency of displacement between Argentina and Paraguay.

The overall HPV infection prevalences for our cases group agrees with previous studies carried out worldwide, showing an increasing viral detection rate associated with the severity of lesions. ${ }^{1}$ In this study, the prevalence of HPV general infection in abnormal cytology coincides with that found by van den Brule et al., ${ }^{23}$ Cromme et al., ${ }^{24}$ and de Roda Husman et al. ${ }^{25}$ in the Netherlands, who applied the same PCR approach.

In all degree of lesions, HPV type 16 predominated significantly. The LSIL samples showed a high prevalence of HPV 16 (77.3\%) compared with other studies done worldwide (45-55\% range of prevalence). ${ }^{1}$ The high HPV 16 prevalence in 
TABLE 6. Association of HPV infection with risk factors in the control group

\begin{tabular}{|c|c|c|c|}
\hline Variable & $\begin{array}{c}\text { No. of } \\
\text { subjects }\end{array}$ & $\begin{array}{c}\text { HPV } \\
\text { positive (\%) }\end{array}$ & OR $(95 \% \mathrm{Cl})$ \\
\hline \multicolumn{4}{|l|}{ Lifetime no. of sex partners } \\
\hline 1 & 51 & 11.8 & 1.0 \\
\hline $2-5$ & 93 & 50.5 & $7.7(4.2-15.6)$ \\
\hline$>5$ & 55 & 58.2 & $10.4(5.3-19.2)$ \\
\hline \multicolumn{4}{|l|}{ Age at first intercourse $(y)$} \\
\hline $22-25$ & 60 & 20.0 & 1.0 \\
\hline$|8-2|$ & 83 & 45.8 & $3.4(2.0-5.6)$ \\
\hline $14-17$ & 56 & 62.5 & $6.6(3.4-9.7)$ \\
\hline \multicolumn{4}{|l|}{ Frequency of displacement } \\
\hline \multicolumn{4}{|l|}{ between countries } \\
\hline Once a week or less & 105 & 31.4 & 1.0 \\
\hline Twice a week or more & 94 & 55.3 & $2.7(1.5-5.2)$ \\
\hline \multicolumn{4}{|l|}{ Use of oral contraceptives } \\
\hline No & 102 & 31.3 & 1.0 \\
\hline Yes & 97 & 54.6 & $2.6(1.3-4.8)$ \\
\hline \multicolumn{4}{|l|}{ Socioeconomic status } \\
\hline Upper/middle class & 118 & 33.9 & 1.0 \\
\hline Low income & 81 & 55.5 & $2.4(1.1-4.3)$ \\
\hline \multicolumn{4}{|c|}{ Placement of permanent residence } \\
\hline Northeastern Argentina & 129 & 38.0 & 1.0 \\
\hline Southern Paraguay & 70 & 51.4 & $1.7(0.8-3.1)$ \\
\hline \multicolumn{4}{|l|}{ Age at first pregnancy (y) } \\
\hline $30-36$ & 42 & 42.8 & 1.0 \\
\hline $21-29$ & 74 & 39.2 & $0.9(0.3-1.7)$ \\
\hline $16-20$ & 83 & 45.8 & $1.1(0.6-1.9)$ \\
\hline
\end{tabular}

HSIL (72.4\%) is only comparable with that found by Sebbelov et al. in a study of a population at high risk for cancer in Greenland. ${ }^{26}$

All ICC samples were HPV positive but $16 \%$ of them were infected with viral types other than HPV $6,11,16$, or 18 , suggesting that other carcinogenic types may be involved.

Sexual behavior was associated with progression of high-degree lesions in infected subjects; permanent residence in Paraguay was also strongly associated with HSIL and ICC, probably due to the absence of regular Pap test screening programs in that country.

The elevated proportion of women infected with carcinogenic viral types and normal cytology is an important finding that must be considered as a relevant challenge. A follow-up study of this subclinical group may provide important data regarding regional characteristics of HPV genital infection and natural history of cervical cancer precursor lesions. Several particular characteristics of this regional population have been associated with either HPV infection (frequency of subject displacement between Argentina and Paraguay) or lesion severity (place of permanent residence). Implementing coordinated public health policies between Argentina and Paraguay, such as a simultaneous Pap test screening program in borderline cities, may help in lowering cervical cancer cases.

\section{ACKNOWLEDGMENTS}

The authors thank Joaquín V. González for excellent technical assistance. This work was supported by a collaborative agreement between the Laboratorio de Biología Molecular Aplicada, FCEQyN, Universidad Nacional de Misiones (Posadas), and the Servicio Virus Oncogénicos, INEI- ANLIS "Dr. Carlos G. Malbrán" (Buenos Aires). This work was partially sponsored by grants from CIDeT and Fundación Alberto J. Roemmers (to SAT), CONICET PIA 7346 and Fundación Mosoteguy (to ART).

\section{REFERENCES}

1. World Health Organization International Agency for Cancer Research. Human papillomaviruses. IARC Monogr Eval Carcinog Risks Hum 1995;64.

2. Coleman M. Trends in cancer incidence and mortality. IARC Sci Publ 1993;121:1-806.

3. Bosch F, Manos M, Muñoz N, et al. Prevalence of human papillomavirus in cervical cancers: a worldwide perspective. J Natl Cancer Inst 1995;87:796-802.

4. Forslund O. Genital Human Papillomaviruses. Studies 
of their occurrence, type spectrum, and expression. Mälmo, Sweden: Lund University Press, 1997, pp. 2570.

5. Hansson B, Forslund O, Bjerre B, et al. Human papillomavirus types in routine cytological screening and at colposcopic examination. Eur J Obstet Gynecol Reprod Biol 1993;52:49-55.

6. Koutsky L, Holmes K, Critchlow C. A cohort study of the risk of cervical intraepithelial neoplasia grade 2 or 3 in relation to papillomavirus infection. $\mathrm{N}$ Engl $\mathrm{J}$ Med 1992;327:1272-1278.

7. Muñoz N, Bosch F. Relación causal entre virus del papiloma humano y cáncer cervicouterino y consecuencias para la prevención. Bol Oficina Sanit Panam 1996;121: 550-566.

8. Villa L, Franco E. Epidemiologic correlates of cervical neoplasia and risk of human papillomavirus infection in asymptomatic women in Brazil. J Natl Cancer Inst 1989; $81: 332-340$

9. Muñoz N, Weadle I, Bosch F, et al. Risk factors for HPV DNA detection in middle-aged women. Sex Transm Dis 1996;23:504-510.

10. Kjaer $S$, de Villiers E, Caglayan $H$, et al. HPV, herpes simplex virus, and other potential risk factors for cervical cancer in a high risk area (Greenland) and a low risk area (Denmark)-a second look. Br J Cancer 1994;67: 830-837.

11. Jantus Lewintre E, Martin de Civetta M, Picconi M, et al. Cancer de cuello uterino en Corrientes (Argentina): tipificacion de virus papiloma humano (HPV) en lesiones cervicales por PCR-hibridacion. Nuevas Tendencias en Oncologia 1998;8:134-139.

12. Schiffman M. Recent progress in defining the epidemiology of HPV infection and cervical neoplasia. J Natl Cancer Inst 1992;84:394-398.

13. zur Hausen H. Human papillomaviruses in the pathogenesis of anogenital cancer. Minireview Virol 1991;184: 9-13.

14. National Cancer Institute Workshop: The 1988 Bethesda system for reporting cervical/vaginal cytological diagnoses. JAMA 1989;262:931-934.

15. Astori G, Pipan C, Muffato G, et al. Detection of HPVDNA in semen, urine, urethral samples by dot blot and PCR. Microbiologica 1995;18:143-149.

16. Bauer H, Greer C, Manos M. Determination of genital human papillomavirus infection by consensus polymerase chain reaction amplification. In: Herrington C, McGree J (eds): Diagnostic Molecular Pathology: A Practical Approach. Oxford: IRL Press, 1992, pp. 131-152.

17. de Roda Husman A, Walboomers J, van den Brule A, et al. The use of general primers GP5 and GP6 elongated at their 3 ends with adjacent highly conserved sequences improves HPV detection by PCR. J Gen Virol 1995;76:1057-1062.

18. Jacobs $\mathrm{M}$, de Roda Husman A, van den Brule A, et al. Group-specific differentiation between high- and lowrisk human papillomavirus genotypes by general primer-mediated PCR and two cocktails of oligonucleotide probes. J Clin Microbiol 1995;33:901-905.

19. Breslow NE, Day NE. Statistical methods in cancer research. Volume I-The analysis of case-control studies. IARC Sci Publ 1980;32:5-338.

20. Villa L. Human papillomaviruses and cervical cancer. Adv Cancer Res 1997;65:321-341.

21. Muñoz N, Bosch F, de Sanjose $S$, et al. The causal link between human papillomavirus and invasive cervical cancer: a population-based case-control study in Colombia and Spain. Int J Cancer 1992;52:743-749.

22. Hildesheim A, Schiffman M, Gravitt P, et al. Persistence of type-specific human papillomavirus infection among cytologically normal women. J Infect Dis 1994; 169:235-240.

23. van den Brule A, Walboomers J, Du Maine $M$, et al Difference in prevalence of human papillomavirus genotypes in cytomorphologically normal cervical smears is associated with a history of cervical intraepithelial neoplasia. Int J Cancer 1991;48:404-408.

24. Cromme F, Meijer C, Snijders P, et al: Analysis of MHC class I and II expression in relation to presence of HPV genotypes in premalignant and malignant cervical lesions. Br J Cancer 1993;67:1372-1380.

25. de Roda Husman A, Walboomers J, Meijer C, et al. Analysis of cytomorphologically abnormal cervical scrapes for the presence of 27 mucosotropic human papillomavirus genotypes using polymerase chain reaction. Int J Cancer 1994;56: 802-806.

26. Sebbelov A, Svendsen C, Jensen H, et al. Prevalence of HPV in premalignant and malignant cervical lesions in Greenland and Denmark: PCR and in situ hybridization analysis on archival material. Res Virol 1994;145:83-92. 


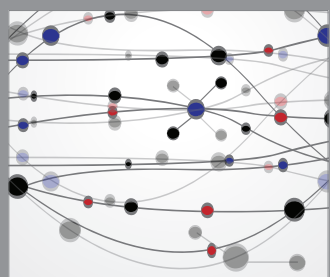

The Scientific World Journal
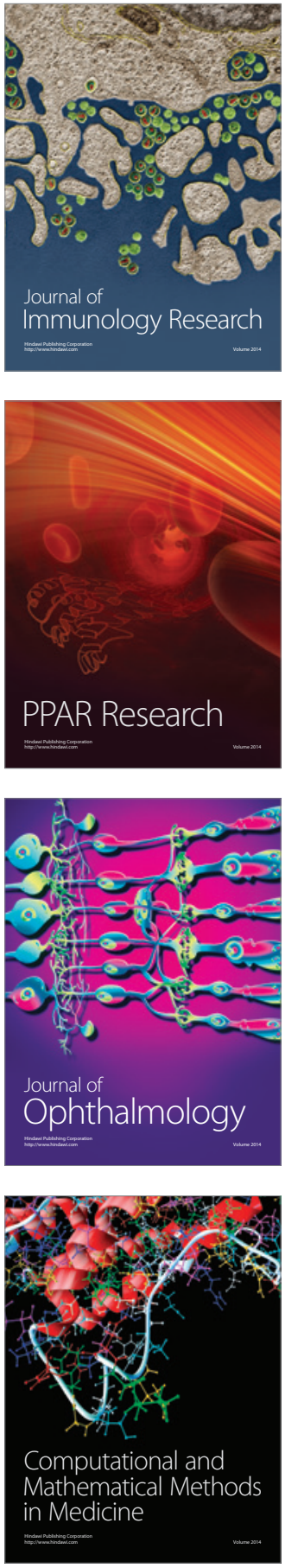

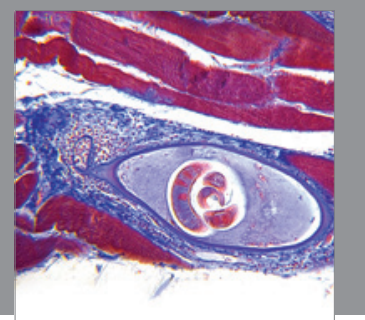

Gastroenterology

Research and Practice
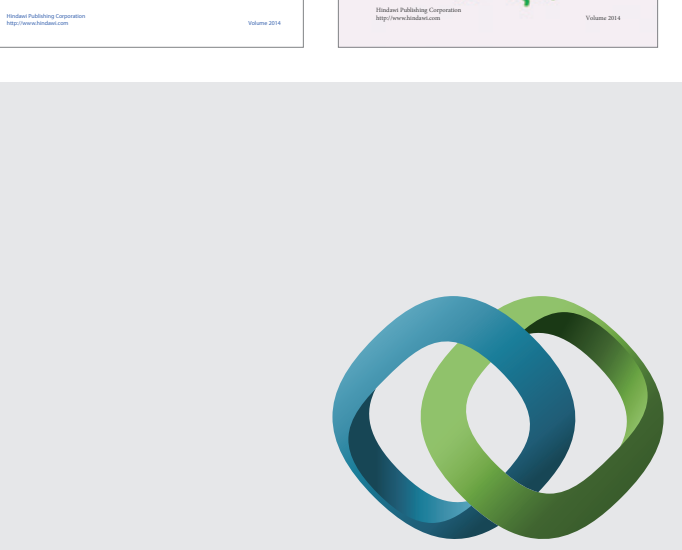

\section{Hindawi}

Submit your manuscripts at

http://www.hindawi.com
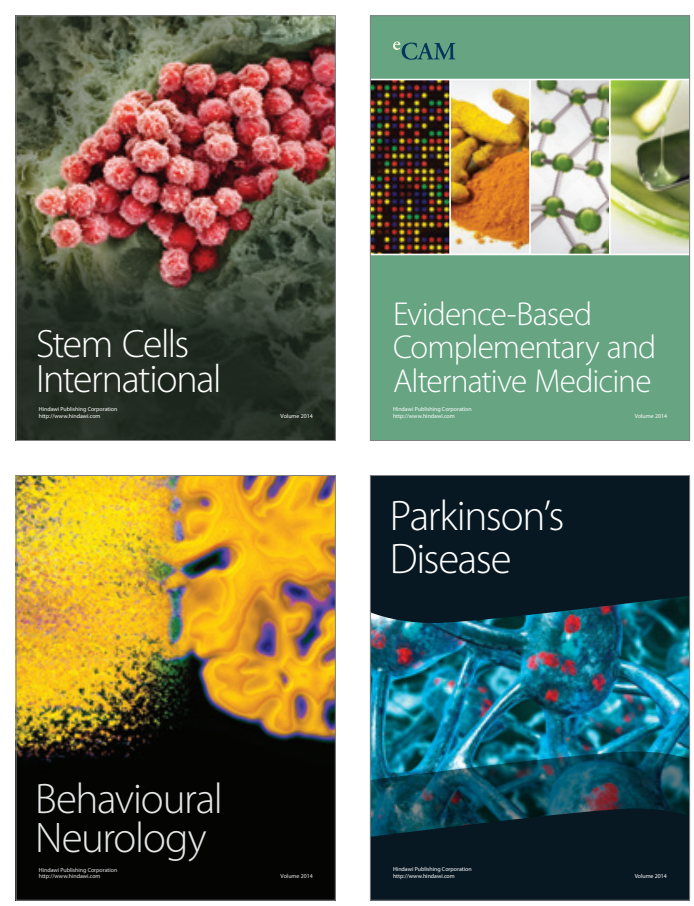

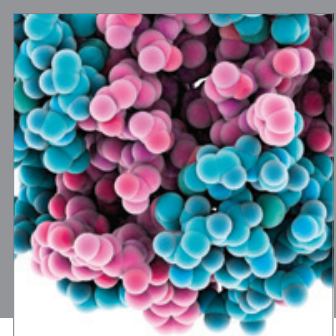

Journal of
Diabetes Research

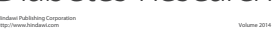

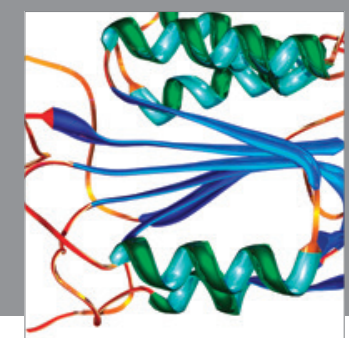

Disease Markers
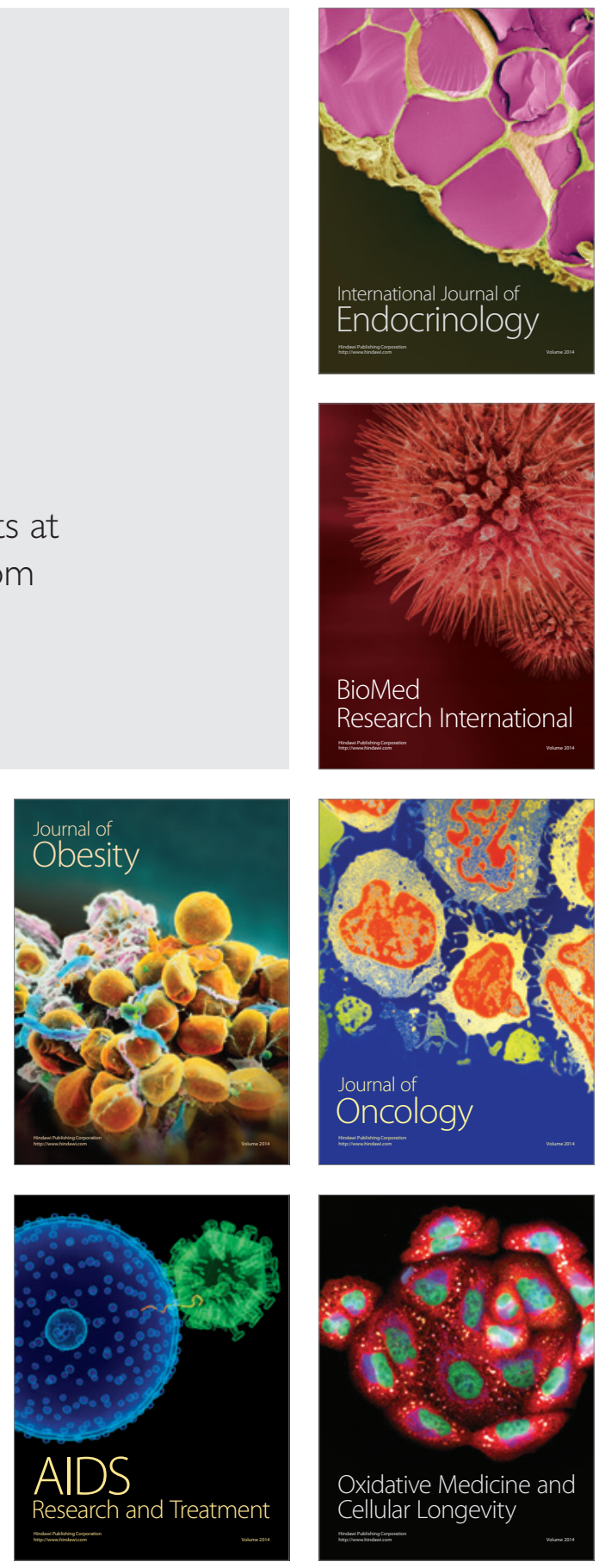